Volume 9, No.5, September - October 2020

International Journal of Advanced Trends in Computer Science and Engineering

Available Online at http://www.warse.org/IJATCSE/static/pdf/file/ijatcse86952020.pdf

https://doi.org/10.30534/ịjatcse/2020/86952020

\title{
Digital Standardization as a tool for effective development of dairy products
}

\author{
Zhazira Shadyarova $^{1}$, Dina Kurmangaliyeva ${ }^{2}$, Gaukhar Yussupova ${ }^{3}$, Zhadyra Salykbayeva ${ }^{4}$, Askar \\ Muratov $^{5}$, Nadezhda Lantseva ${ }^{6}$, Begjan Kalemshariv ${ }^{7}$ \\ ${ }^{1}$ Kazakh Agrotechnical University named after S. Seifullin, Nur-Sultan, Kazakhstan, kadr_90.taz@mail.ru \\ ${ }^{2}$ Kazakh Agrotechnical University named after S. Seifullin, Nur-Sultan, Kazakhstan, kurmangaliyeva.dina@bk.ru \\ ${ }^{3}$ Kazakh Agrotechnical University named after S. Seifullin, Nur-Sultan, Kazakhstan, researchkz@mail.ru \\ ${ }^{4}$ Atyrau State University named after Kh. Dosmukhamedov, Atyrau, Kazakhstan, salykbaeva.zhadyra@bk.ru \\ ${ }^{5}$ Kazakh Agrotechnical University named after S. Seifullin, Nur-Sultan, Kazakhstan, amuratov2020@inbox.ru \\ ${ }^{6}$ Novosibirsk State Agrarian University, Novosibirsk, Russia, nadya.lantseva@inbox.ru \\ ${ }^{7}$ Kazakh Agrotechnical University named after S. Seifullin, Nur-Sultan, Kazakhstan, kalemshariv@list.ru
}

\begin{abstract}
This article presents a sequence of actions processed using computer analysis in the development of a new product-goat's milk yogurt with dates, which regulates the norms, methods and controls, which allows not only to reliably, but also to quickly determine the main properties of products. In addition, studies were conducted to confirm the compliance of a new dairy product-yogurt from goat's milk. As a result, we received a dietary dairy product-yogurt from goat's milk with dates with a protein content of $2.83 \mathrm{~g}$, fat $2.13 \mathrm{~g}$, carbohydrates-6.72 g, humidity-87.43 g, ash-0.89 g, energy value-57 / $238 \mathrm{kcal} / \mathrm{kJ} / 100 \mathrm{~g}$ and a shelf life set at a temperature of $-2-6^{\circ} \mathrm{C}$ for 5 days.
\end{abstract}

Key words : goat's milk; yogurt; computer processing; quality; standards; energy value; safety; nutritional value; organoleptic characteristics; analysis; dairy product

\section{INTRODUCTION}

Milk and milk products are essential food products for human nutrition, especially for infants, kids and older people. The major value of the milk is that all food components in milk are well balanced, easy digested and almost completely consumed by human body. On chemical composition of milk there is nothing quite similar food. Milk is rich in vitamin A and D, and also has ascorbic acid, riboflavin, thiamine and nicotinic acid [1].

In the agricultural sector great attention is paid to improving the quality of dairy products . This problem is one of the most important and complex, as it has not only a sectoral, but also an intersectoral character. At the same time, one of the most important tasks of standardization is the creation of standards governing scientifically sound quality standards, methods and means of control, that allow not only reliably, but also to quickly determine the basic properties of products that characterize its consumer value.

The formation of market relations, their further development and improvement requires a clear approach to the characteristics of products as the main object of commercial activity. As a result of the rapid development of the production of food products with fundamentally new properties, improvement and expansion of the assortment of dairy products, the need for flexible standardization arose, reflecting the essential features, characteristics and properties of a product.

A significant impact on the quality of finished products is exerted by: quality of raw materials, conditions and methods of production, packaging, transportation, and storage. The following requirements are set for dairy products, regulated by regulatory documents: Technical Regulation of the Customs Union 033/2013 "On the Safety of Milk and Dairy Products" (hereinafter referred to as TR CU); Sanitary rules and regulations 2.3.2.1078-2001 "Food raw materials and food products. Hygienic requirements for food safety and nutritional value. Sanitary and epidemiological rules and regulations "(hereinafter referred to as Sanitary rules and regulations); GOST 23327-98; GOST 5867-90; GOST 3626-73; GOST 15113.8-77. Milk and dairy products of industrial production must be produced according to regulatory or technical documentation developed, agreed and approved in the prescribed manner.

Nutrition is a vital necessity of a person. Currently, there is a notable increase in the understanding that food has a significant impact on human beings. It gives energy, strength, development, and with proper use of it health as well. It can be stated with certainty that human health is $70 \%$ dependent on nutrition. Food is often the main source of most diseases, but with its help one can get rid of long-term deceases. No matter how tempting the colorful palette of food products and ready to use products is, the problems associated with the 
production of food that modern civilization has generated are great. High blood cholesterol, obesity, caries, diabetes, fat metabolism, hypertension, constipation, high uric acid in the blood or gout - this is an incomplete list of the so-called "diseases of civilization" caused by malnutrition.

Yogurt is an extremely popular fermented milk product that has many proven beneficial properties. It is rich in important vitamins and minerals, helps maintain intestinal microflora, improves the immune system. 1 serving of yogurt (about 245 g) contains half the daily intake of calcium. Irish studies show that adequate calcium intake can increase bone density and slow down the removal of valuable minerals. The effect is especially noticeable in the elderly, as well as in women during the postmenopausal period. Dairy product is rich in vitamins B2 and B12.

According to scientists, cyanocobalamin (B12) is extremely important for the full development of the fetus during pregnancy. This biologically active substance also protects the gastric mucosa from damage caused by the use of "harmful" food. Yogurt saturates the human body with phosphorus, magnesium and potassium. These minerals are extremely important for the course of all metabolic processes, maintaining blood pressure and bone mineral density. A special role is given to vitamin $\mathrm{D}$, which is abundant in living yogurt cultures. According to studies, vitamin D increases bone mineralization, reduces the activity of resorption. Yogurt is rich in protein, which helps to control appetite and promote weight loss. 1 cup of yogurt contains about 12 grams of protein. This is a fairly high indicator when compared with other dairy products. Proteins are not only a valuable building material for the whole organism, but also favorably affect body weight. The combination of proteins with unsaturated fats present in yogurt, according to scientists, leads to a decrease in body weight $[2,3,4,5]$.

\section{MATERIALS AND METHODS}

When analyzing the consumer market, we found that dairy products, including yogurt, constitute an important part of the diet of Kazakhstani consumers. Therefore, our goal was to expand the standardization object in the form of a national standard for products "Yogurt with dates from goat's milk", which will reflect the quality and safety standards, methods and means of control, that will allow us not only to reliably, but also quickly determine the main products properties characterizing its consumer value, as well as introduce a new dairy product at the processing enterprise "Breeding goat farm Zerenda", LLP located in the village of Kazhimukan Tselinogradsk the district of Akmola region of the Republic of Kazakhstan.

Experimental studies were carried out in the period from 2018-2019 on the basis of "Breeding goat farm Zerenda", LLP located in the village of Kazhimukan Tselinogradsk the district of Akmola region of the Republic of Kazakhstan.

As an object of research, yogurt was used, containing as initial components: goat milk, sourdough in the form of a bacterial concentrate and dates.
The results of the analysis of goat milk yogurt production with dates were carried out at the Kazakh Academy of Nutrition. To obtain information on the main aspects of the population's demand for dairy products produced by domestic dairy enterprises, market research was carried out.

120 people were interviewed, the age of the respondents was 19-60 years, the number of men and women who participated in the survey was the same.

The survey involved consumers of dairy products of all income levels, in accordance with the average statistics.

Evaluating each property by a point system, we used the digital discrete interval scale shown in Table 1, which shows the deviation from pre-established requirements for the organoleptic properties of the product.

Table 1: Digital discrete interval scale showing the magnitude of the deviation in the assessment.

\begin{tabular}{|l|l|}
\hline Points & \multicolumn{1}{c|}{ Oral Description } \\
\hline 5 & $\begin{array}{l}\text { No deviation from pre-established } \\
\text { requirements for organoleptic properties }\end{array}$ \\
\hline 4 & $\begin{array}{l}\text { Minimum deviation from pre-established } \\
\text { requirements for organoleptic properties }\end{array}$ \\
\hline 3 & $\begin{array}{l}\text { Marked deviation from pre-established } \\
\text { requirements for organoleptic properties }\end{array}$ \\
\hline 2 & $\begin{array}{l}\text { Significant deviation from pre-established } \\
\text { requirements for organoleptic properties }\end{array}$ \\
\hline 1 & $\begin{array}{l}\text { Very significant deviation from } \\
\text { pre-established requirements for organoleptic } \\
\text { properties }\end{array}$ \\
\hline
\end{tabular}

Each expert evaluated samples of milk and dairy products randomly. Samples were presented in such a way that the experts could not mix them up. The experts were instructed to conduct an organoleptic assessment of the technical characteristics in an appropriate, regularly repeated manner (sample size in the mouth, chewing time, etc.). Appropriate cleaning agents (for example, rinsing the mouth with clean water at room temperature) were used to prevent the transfer of any irritants that might affect the evaluation of the next sample.

To regulate and coordinate the work of experts, at least two calibration samples of each type of product were evaluated and the results obtained before the assessment began were discussed. It is assumed that one calibration sample must meet the requirements for organoleptic characteristics (control sample). Calibration samples were available at the time of evaluation.

The experts analyzed the samples independently of each other, without communicating with each other.

There are two types of methods used to determine the quality of food products, - organoleptic and laboratory (measuring). With the help of the first, the consistency, smell, taste, color and appearance are determined using such sensory organs as: vision, hearing, smell and touch. In some cases, a score is introduced to determine the quality of the product more accurately. Using the measuring method, chemical, physical, 
physiological and microbiological indicators of food quality are determined.

The organoleptic characteristics of the products were determined in accordance with GOST R ISO 22935-2-2011

Group H19 National Standard Of The Russian Federation Milk And Dairy Products Organoleptic analysis Part 2 Recommended organoleptic assessment methods.

This method is the basis for organoleptic evaluation of dairy products. The conditions for this method are applicable to liquid fermented milk products and high viscosity fermented milk products and Part 3 of the Guidelines for assessing the conformity of technical specifications for products to determine organoleptic properties by scoring.

Studies on the determination of proteins were carried out in accordance with GOST 23327-98 Group H19 Interstate Standard Milk And Dairy Products Method for measuring the mass fraction of total nitrogen according to Kjeldahl and determining the mass fraction of protein.

Fats were determined according to GOST 5867-90. Group H 19. Interstate standard milk and dairy products Methods for the determination of fat. Studies on the determination of carbohydrates were determined by method of I.M.Skurikhin "Chemical composition of food products" Book 1: Reference tables for the content of basic nutrients and the energy value of food $[6,7,8,9]$.

The moisture content was determined according to GOST 3626-73 Milk and dairy products. Methods for the determination of moisture and dry matter (as Amended No. 1, $2,3)$.

Studies to determine the mass fraction of SOMO in products of milk-containing and milk components were carried out according to GOST R 54761-2011 Milk and dairy products. Methods for determining the mass fraction of dry skim milk residue.

Studies on the determination of ash were carried out according to GOST 15113.8-77 food concentrates. Methods for the determination of ash. The method is based on the production of ash - the residue of mineral substances formed in the roseltate of the complete burning of the organic part of a portion of the product and subsequent weight determination of the mass fraction of ash $[10,11,12,13,14]$.

Studies of the energy value of products were carried out according to the method of I.M. Skurikhin "Chemical composition of food products" Book 1: Reference tables for the content of basic nutrients and the energy value of food [6]. To create a new product - yogurt with dates made from goat milk contain dates, we also analyzed the norms for the fermented milk product yogurt of different fat contents and berries - dates (Tables 2 and 3).

\section{RESULTS AND DISCUSSION}

In the course of marketing research, first of all, groups of consumers with different levels of income were identified (consumers themselves characterized their level of income). The characteristics of the groups are shown in table 4. The distribution of respondents by group is shown in figure 1 .

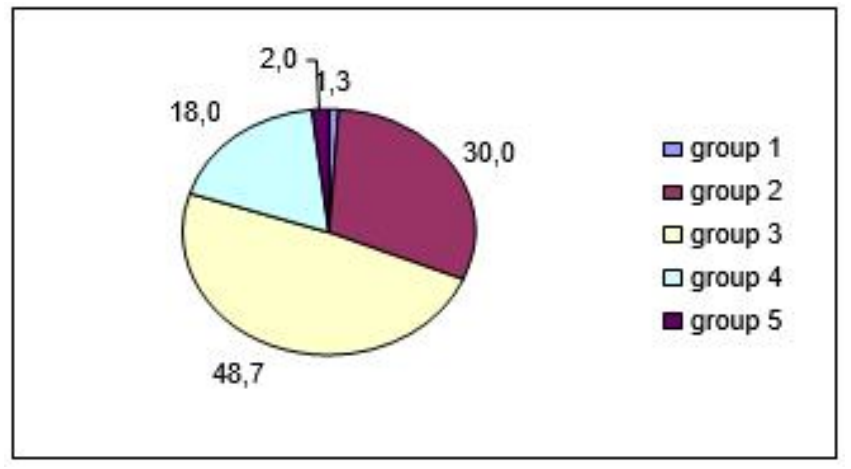

Figure 1: Distribution of respondents by group according to income level, \%

Table 4: Characteristics of Respondent groups according to income level

\begin{tabular}{|l|l|}
\hline Group & Standard of living \\
\hline Group 1 & $\begin{array}{l}\text { High standard of living (we can buy an } \\
\text { apartment or a car) }\end{array}$ \\
\hline Group 2 & $\begin{array}{l}\text { Average standard of living (income is enough } \\
\text { for everything except very expensive } \\
\text { purchases) }\end{array}$ \\
\hline Group 3 & $\begin{array}{l}\text { The standard of living is below average (there } \\
\text { is enough money for food and clothing, but } \\
\text { buying long-term goods is difficult) }\end{array}$ \\
\hline Group 4 & $\begin{array}{l}\text { Low standard of living (enough money for } \\
\text { food, but buying clothes is difficult) }\end{array}$ \\
\hline Group 5 & $\begin{array}{l}\text { Critical standard of living (money is not } \\
\text { enough even for food) }\end{array}$ \\
\hline
\end{tabular}

It was found that the majority of respondents, namely 48.7 per cent belong to the third group, i.e. with income below average (enough money for food and clothes, but buying durable goods is a challenge); $30 \%$ of respondents belong to the second group, i.e. with the average standard of living (income is enough for all except the very expensive acquisitions).

Next, a "questionnaire" consisting of 15 questions was created for the survey of consumers. The results of the survey of some questions are presented below:

"Which manufacturers of dairy products do You know?" The milk processing enterprises most often remembered by consumers were "Food master" - 80\%, "Rodina" - 48\%, "Zenchenko" - 45\%, "Zerenda" - 13\%,"Natizhe "-10\%," Selo Lesnoe " - 10\%," Emil " - 6\%," Arshaly " - 5\%, and others- $10 \%$. These enterprises constitute the main structure of the dairy market in the minds of consumers in Nur-Sultan, as it is about them that the respondents remembered in the first place. This suggests that these companies are associated with a product category such as high-quality dairy products.

"Which groups of dairy products do you buy more often and how much of a one-time purchase?". The most popular among citizens are milk, sour cream and other fermented milk products - over the past 3 months, they were bought by $85 \%$, $60 \%$ and $70 \%$ of respondents, respectively. The volume of one-time purchase of any type of dairy products for the majority of consumers (65\% of respondents) is in the range of 0.3-1 liter, which can be considered the optimal packaging for 
dairy products. As for the frequency of purchase, milk is bought as an addition to regular food 4-5 times a week, sour milk products-sour cream, yogurt and cottage cheese - 2-4 times a week, and butter and cheeses, Kurt, cheese - 1-2 times a month.

"What criteria are determinant when choosing dairy products?". According to the analysis of criteria that influence the choice of dairy products, the data obtained are as follows: the most important factor in making a decision to buy dairy products is the manufacturer $-80 \%$, the second place is the price $-48 \%$, and the third place is the appearance $-45 \%$.

Next, we identified and studied the criteria for the organoleptic qualities of Goat's milk yogurt with dates. The results of the study are presented in table 5 .

Table 5: Organoleptic indicators for the organization standard of yogurt with dates from goat's milk

\begin{tabular}{|l|l|l|}
\hline Indicator & Requirements & Research result \\
\hline Consistency & $\begin{array}{l}\text { Homogeneous } \\
\text { moderately } \\
\text { viscous liquid }\end{array}$ & $\begin{array}{l}\text { When adding dates, the } \\
\text { consistency is more } \\
\text { viscous. With small } \\
\text { pieces of fruit. }\end{array}$ \\
\hline $\begin{array}{l}\text { Taste and } \\
\text { smell }\end{array}$ & $\begin{array}{l}\text { Fermented milk } \\
\text { with a } \\
\text { pronounced taste } \\
\text { of pasteurization. } \\
\text { Smell - } \\
\text { characteristic of a } \\
\text { dairy product }\end{array}$ & $\begin{array}{l}\text { When adding } \\
\text { dates-moderately sweet } \\
\text { and sour taste. } \\
\text { Corresponds to the taste } \\
\text { of dates. } \\
\text { With a barely } \\
\text { noticeable specific } \\
\text { smell. }\end{array}$ \\
\hline Color & $\begin{array}{l}\text { Milk-cream, } \\
\text { uniform }\end{array}$ & $\begin{array}{l}\text { High cream color, } \\
\text { small particles of dates } \\
\text { are allowed evenly } \\
\text { distributed throughout } \\
\text { the mass }\end{array}$ \\
\hline
\end{tabular}

Then we made an experimental batch of products of the newly created product- Goat's milk yogurt with dates and evaluated the quality of yogurt from goat's milk and yogurt with dates from goat's milk

Comparative results of tasting fermented milk products-goat's milk yogurt and yogurt with dates are presented in table 5-6. Expert evaluation of the results of fermented milk products-yogurt, which was attended by 5 experts, showed that the products are of excellent quality

To determine the physical and chemical parameters of goat's milk yogurt with dates, 5 repetitions of product samples were studied (table. 7).

Next, the comparative characteristics of the physicochemical parameters of goat's milk yogurt with dates were determined (Table 8).

As a result of the conducted research, norms were obtained for the development of a regulatory document in the form of the organization's standard for fermented milk products-yogurt with dates from goat's milk (table. 9).

\section{CONCLUSION}

The new product developed by us - goat's milk yogurt with dates meets all the quality and safety requirements regulated by regulatory documents, and also had possessed health-promoting properties. Experimentally, the shelf life of products is 5 days at a temperature of $-2-6^{\circ} \mathrm{C}$ was identified. According to the results of this work, was developed and a patent application was formalized for "Goat's milk Yogurt with dates".

\section{ACKNOWLEDGEMENT}

This study was funded by the Ministry of Education and Science of the Republic of Kazakhstan

\section{REFERENCES}

(Periodical style)

1. S. Chen, B. Mulgrew, and P. M. Grant. A clustering technique for digital communications channel equalization using radial basis function networks, IEEE Trans. on Neural Networks, Vol. 4, pp. 570-578, July 1993.

2. Aigul Omaralieva, Gulbanu Karmanova, Tolkyn Kozhakhmetova, Zhanar Safuani, Almira Bekturganova, Dina Kurmangalieva, Ardak Bekturganova. Review of Technology of Kazakh National Milk Product - Kurt. Research Journal of Pharmaceutical, Biological and Chemical Sciences 7(6): 12217, 2016.

3. Popova M. A., Rebezov M. B., Gayazova A. O., Lukinykh S. V. Evaluation of the quality and safety of the developed yogurt. Young scientist. 10:199-202, 2014. https://moluch.ru/archive/69/11878.

4. Skurikhina I. M. "Chemical composition of food products" Book 1: Reference tables of the content of basic food substances and the energy value of food products. Agropromizdat. Leningrad Department, 1987.

5. Medvedev Zh. Yogurt. Useful product or elixir of youth. Vser.Econ.Journal.-Grown.Acad. Sciences 8:183-189, 2005.

6. GOST R ISO 22935-2-2011 Group H19 NATIONAL STANDARD of the RUSSIAN FEDERATION MILK and DAIRY PRODUCTS Organoleptic analysis Part 2 Recommended methods of organoleptic evaluation.

7. GOST R ISO 22935-3-2011 Group H19 NATIONAL STANDARD of the RUSSIAN FEDERATION MILK and DAIRY products Organoleptic analysis Part 3 Guidelines for assessing compliance with product specifications for determining organoleptic properties by scoring points.

8. GOST 23327-98 group H19 INTERSTATE STANDARD MILK and DAIRY PRODUCTS Method for measuring the mass fraction of total nitrogen by Kjeldahl and determining the mass fraction of protein.

9. GOST 5867-90. Group H 19. Interstate standard milk and dairy Products methods for determining fat. 
10. GOST R 54761-2011 Milk and dairy products. Methods for determining the mass fraction of dry skim milk residue

11. GOST 3626-73 Milk and dairy products. Methods for determining moisture and dry matter.

12. GOST 15113.8-77 Food concentrates. Methods for determination of ash.

13. Omayma El Majdoubi et al. Artificial Intelligence Approach for Multi-Objective Design Optimization of Composite Structures: Parallel Genetic Immigration. International Journal of Advanced Trends in Computer Science and Engineering, 9(3), May - June 2020, 2508 - 2516

14. Rajesh T. Jadhav et al. A Real Time Hardware Co-Simulation of Linearization of Nonlinear Sensor using ANFIS Linearizer. International Journal of Advanced Trends in Computer Science and Engineering, 9(3), May - June 2020, 2550 - 2556 
Table 2: The main indicators and characteristics of the fermented milk product yogurt

\begin{tabular}{|c|c|c|c|c|c|c|c|c|c|c|c|c|c|c|c|c|c|c|c|c|c|}
\hline \multirow{3}{*}{$\underset{\Xi}{\stackrel{x}{\Xi}}$} & \multirow{3}{*}{ Product } & \multirow[b]{2}{*}{ 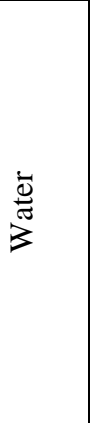 } & \multirow[b]{2}{*}{ 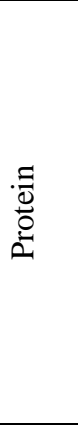 } & \multirow[b]{2}{*}{ 苟 } & \multicolumn{2}{|c|}{$\begin{array}{c}\text { Carbohydr } \\
\text { ates }\end{array}$} & \multirow{2}{*}{ 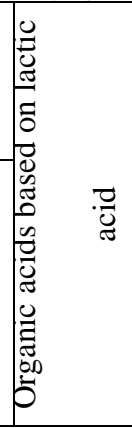 } & \multirow[b]{2}{*}{$\frac{5}{\frac{1}{4}}$} & \multicolumn{6}{|c|}{ Minerals } & \multicolumn{6}{|c|}{ Vitamins } & \multirow[b]{2}{*}{ 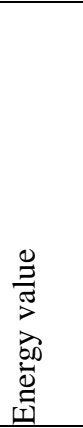 } \\
\hline & & & & & $\begin{array}{l}0 \\
\mathscr{0} \\
\stackrel{0}{0} \\
\stackrel{\Xi}{\Xi}\end{array}$ & $\begin{array}{l}0 \\
\mathscr{0} \\
\stackrel{0}{0} \\
\bar{\omega}\end{array}$ & & & $\mathrm{Na}$ & $\mathrm{K}$ & $\mathrm{Ca}$ & $\mathrm{Mg}$ & $\mathrm{P}$ & $\mathrm{Fe}$ & A & 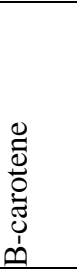 & $\mathrm{B}_{1}$ & $\mathrm{~B}_{2}$ & $\mathrm{PP}$ & $\mathrm{C}$ & \\
\hline & & \multicolumn{7}{|c|}{ Grams } & \multicolumn{12}{|c|}{ milligrams } & kcal \\
\hline 1 & 2 & 3 & 4 & 5 & 6 & 7 & 8 & 9 & 10 & 11 & 12 & 13 & 14 & 15 & 16 & 17 & 18 & 19 & 20 & 21 & 22 \\
\hline 4.1 .47 & $1.5 \%$ fat yogurt & 88,0 & 5,0 & 1,5 & 3,5 & - & 1,30 & 0,7 & 50 & 152 & 124 & 15 & 95 & 0,1 & 0,01 & сл. & 0,03 & 0,15 & 0,15 & 0,6 & 51 \\
\hline 4.1 .48 & $1.5 \%$ fat sweet yogurt & 83,0 & 5,0 & 1,5 & 3,5 & 5,0 & 1,30 & 0,7 & 50 & 150 & 124 & 15 & 95 & 0,1 & 0,01 & сл. & 0,03 & 0,15 & 0,15 & 0,6 & 70 \\
\hline 4.1 .49 & $3.2 \%$ fat yogurt & 86,3 & 5,0 & 3,2 & 3,5 & - & 1,30 & 0,7 & 52 & 147 & 122 & 15 & 96 & 0,1 & 0,02 & 0,01 & 0,04 & 0,20 & 0,15 & 0,6 & 66 \\
\hline 4.1 .50 & $3.2 \%$ fat sweet yogurt & 81,3 & 5,0 & 3,2 & 3,5 & 5,0 & 1,30 & 0,7 & 50 & 140 & 119 & 14 & 91 & 0,1 & 0,02 & 0,01 & 0,03 & 0,15 & 0,15 & 0,6 & 85 \\
\hline 4.1 .51 & $6 \%$ fat yogurt & 83,5 & 5,0 & 6,0 & 3,5 & - & 1,30 & 0,7 & 50 & 147 & 124 & 14 & 92 & 0,1 & 0,03 & 0,02 & 0,03 & 0,15 & 0,15 & 0,6 & 91 \\
\hline 4.152 & $6 \%$ fat sweet yogurt & 78,5 & 5,0 & 6,0 & 3,5 & 5,0 & 1,30 & 0,7 & 50 & 137 & 122 & 14 & 92 & 0,1 & 0,03 & 0,02 & 0,03 & 0,15 & 0,15 & 0,6 & 110 \\
\hline
\end{tabular}


Table 3: The main regulatory indicators of berries

\begin{tabular}{|c|c|c|c|c|c|c|c|c|c|c|c|c|c|c|c|c|c|c|c|c|c|}
\hline \multirow{3}{*}{$\underset{\Xi}{\stackrel{x}{\Xi}}$} & \multirow{3}{*}{$\begin{array}{l}\text { Pro } \\
\text { duct }\end{array}$} & \multirow[b]{2}{*}{$\begin{array}{l}\overline{\bar{J}} \\
\bar{z} \\
3\end{array}$} & \multirow[b]{2}{*}{ 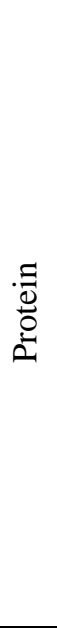 } & \multirow[b]{2}{*}{ 氙 } & \multicolumn{2}{|c|}{$\begin{array}{c}\text { Carbohydr } \\
\text { ates }\end{array}$} & \multirow{2}{*}{\multicolumn{2}{|c|}{ 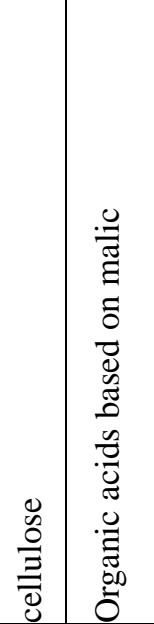 }} & \multirow[b]{2}{*}{$\frac{n}{4}$} & \multicolumn{6}{|c|}{ Minerals } & \multicolumn{4}{|c|}{ Vitamins } & \multicolumn{2}{|c|}{ 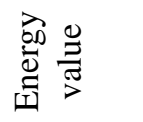 } \\
\hline & & & & & 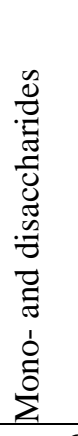 & 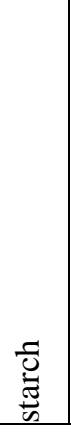 & & & & $\mathrm{Na}$ & K & $\mathrm{Ca}$ & $\mathrm{Mg}$ & $\mathrm{P}$ & $\mathrm{Fe}$ & 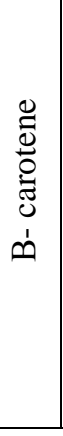 & B1 & B2 & PP & $\mathrm{C}$ & \\
\hline & & \multicolumn{8}{|c|}{ Grams } & \multicolumn{10}{|c|}{ milligrams } & \multicolumn{2}{|c|}{ kcal } \\
\hline 1 & 2 & 3 & 4 & 5 & 6 & 7 & 8 & 9 & 10 & 11 & 12 & 13 & 14 & 15 & 16 & 17 & 18 & 19 & 20 & 21 & 22 \\
\hline $\begin{array}{c}6.3 . \\
9\end{array}$ & Fig & $\begin{array}{c}82 \\
0\end{array}$ & 0,7 & 0,2 & 11,2 & сл. & 2,5 & 0,5 & 1,1 & 18 & 190 & - & - & - & 3,2 & $\begin{array}{c}0,0 \\
5\end{array}$ & $\begin{array}{c}0,0 \\
6\end{array}$ & $\begin{array}{c}0,0 \\
5\end{array}$ & $\begin{array}{c}0,0 \\
5\end{array}$ & 2 & 49 \\
\hline $\begin{array}{r}6.3 . \\
17\end{array}$ & Dates & $\begin{array}{c}20 \\
0\end{array}$ & 2,5 & - & 68,5 & - & 3,6 & 0,3 & 1,5 & 32 & 370 & 65 & 69 & 56 & 1,5 & Сл. & $\begin{array}{c}0,0 \\
5\end{array}$ & $\begin{array}{c}0,0 \\
5\end{array}$ & $\begin{array}{c}0,8 \\
0\end{array}$ & 0,3 & 271 \\
\hline
\end{tabular}

Table 6: Statistical processing of tasters ' ratings on organoleptic indicators of samples of yoghurts from goat's milk produced by "Breeding goat farm Zerenda", LLP

\begin{tabular}{|c|c|c|c|c|c|c|c|c|c|c|c|c|}
\hline \multirow{2}{*}{ Indicators } & \multicolumn{5}{|c|}{ Score } & K & $\Sigma_{\mathrm{Xi}}$ & $\bar{X}$ & & $\bar{X}$ & $\mathrm{~S}$ & $\overline{\bar{X}} *$ \\
\hline & $\begin{array}{l}\text { Exp } \\
\text { ert } 1\end{array}$ & $\begin{array}{l}\text { Expert } \\
2\end{array}$ & $\begin{array}{l}\text { Expert } \\
3\end{array}$ & $\begin{array}{l}\text { Expert } \\
4\end{array}$ & $\begin{array}{l}\text { Expert } \\
5\end{array}$ & \multicolumn{7}{|c|}{ Absolute value } \\
\hline 1. Appearance & 9 & 8 & 9 & 8 & 9 & 3 & 43 & 8,6 & 371 & $\begin{array}{l}73, \\
9\end{array}$ & $\begin{array}{l}0,5 \\
4\end{array}$ & 25,8 \\
\hline 2. Color & 8 & 9 & 8 & 9 & 9 & 1,5 & 43 & 8,6 & 371 & $\begin{array}{l}73, \\
9\end{array}$ & $\begin{array}{l}0,5 \\
4\end{array}$ & 12,9 \\
\hline 3. Smell & 9 & 8 & 9 & 8 & 9 & 2,0 & 43 & 8,6 & 371 & $\begin{array}{l}73, \\
9\end{array}$ & $\begin{array}{l}0,5 \\
5\end{array}$ & 17,2 \\
\hline 4. Taste & 9 & 9 & 8 & 8 & 9 & 2,0 & 43 & 8,6 & 371 & $\begin{array}{l}73, \\
9\end{array}$ & $\begin{array}{l}0,5 \\
4\end{array}$ & 17,2 \\
\hline $\begin{array}{l}5 . \\
\text { Consis-tency }\end{array}$ & 8 & 9 & 8 & 8 & 8 & 1,5 & 41 & 8,2 & 337 & $\begin{array}{l}67, \\
24\end{array}$ & $\begin{array}{l}0,4 \\
4\end{array}$ & 12,3 \\
\hline
\end{tabular}

$\Sigma=93,4$ 
Table 7: Statistical processing of tasters' ratings on organoleptic parameters of samples goat's milk yogurt with dates

\begin{tabular}{|c|c|c|c|c|c|c|c|c|c|c|c|c|}
\hline \multirow{2}{*}{ Indicators } & \multicolumn{5}{|c|}{ Score } & K & $\begin{array}{l}\Sigma \\
\mathrm{Xi}\end{array}$ & $\bar{X}$ & $\frac{\Sigma}{X}_{\mathrm{i} 2}$ & $\bar{X}_{2}$ & S & $\begin{array}{c}\bar{X} * \\
\mathrm{~K}\end{array}$ \\
\hline & $\begin{array}{c}\text { Expert } \\
1\end{array}$ & $\begin{array}{c}\text { Expert } \\
2\end{array}$ & $\begin{array}{c}\text { Expert } \\
3\end{array}$ & $\begin{array}{c}\text { Expert } \\
4\end{array}$ & $\begin{array}{c}\text { Expert } \\
5\end{array}$ & \multicolumn{7}{|c|}{ Absolute value } \\
\hline Appearance & 9 & 8 & 9 & 8 & 9 & 3 & 43 & $\begin{array}{l}8, \\
6\end{array}$ & 371 & 73,9 & $\begin{array}{c}0,5 \\
4\end{array}$ & 25,8 \\
\hline Color & 9 & 9 & 8 & 9 & 8 & 1,5 & 43 & $\begin{array}{l}8, \\
6\end{array}$ & 371 & 73,9 & $\begin{array}{c}0,5 \\
4\end{array}$ & 12,9 \\
\hline Smell & 9 & 9 & 9 & 9 & 9 & 2,0 & 45 & $\begin{array}{c}9, \\
0\end{array}$ & 405 & 81,0 & 0,0 & 18,0 \\
\hline Taste & 9 & 9 & 8 & 8 & 9 & 2,0 & 43 & $\begin{array}{c}8, \\
6\end{array}$ & 371 & 73,9 & $\begin{array}{c}0,5 \\
4\end{array}$ & 17,2 \\
\hline Consistency & 8 & 9 & 8 & 8 & 9 & 1,5 & 42 & $\begin{array}{l}8, \\
4\end{array}$ & 354 & 70,6 & $\begin{array}{c}0,5 \\
4\end{array}$ & 12,6 \\
\hline
\end{tabular}

$\Sigma=95,1$ (100-80 points - excellent quality; 75-60 points - good quality; 59-50 points-satisfactory).

Table 8: Physical and chemical parameters of goat's milk yogurt with dates

\begin{tabular}{|c|c|c|c|c|c|c|}
\hline \multirow{2}{*}{$\begin{array}{l}\text { Name of } \\
\text { indicators, units } \\
\text { of measurement }\end{array}$} & \multicolumn{5}{|c|}{ Goat's milk yogurt with dates } & \multirow{2}{*}{$\begin{array}{l}\text { Designation of the } \\
\text { regulatory } \\
\text { document for test } \\
\text { methods }\end{array}$} \\
\hline & $\begin{array}{l}\text { Sample \#1 } \\
\text { September, } \\
2018 \text {. }\end{array}$ & $\begin{array}{l}\text { Sample \#2 } \\
\text { December, } \\
2018 .\end{array}$ & $\begin{array}{l}\text { Sample \#3 } \\
\text { March, } 2019 .\end{array}$ & $\begin{array}{l}\text { Sample \#4 } \\
\text { June, } 2019 .\end{array}$ & $\begin{array}{l}\text { Sample \#5 } \\
\text { September, } \\
2019\end{array}$ & \\
\hline \multicolumn{7}{|l|}{$\begin{array}{l}\text { Nutritional } \\
\text { value, } \mathrm{g} / \mathrm{100 \textrm {g }} \text { : }\end{array}$} \\
\hline $\begin{array}{l}\text { Proteins, at least } \\
\text { (for dairy } \\
\text { products-in the } \\
\text { milk base) }\end{array}$ & $2,83 \pm 0,002$ & $2,82 \pm 0,002$ & $2,83 \pm 0,002$ & $2,83 \pm 0,002$ & $2,82 \pm 0,002$ & GOST 23327-98 \\
\hline Fats & $2,13 \pm 0,002$ & $2,15 \pm 0,002$ & $2,14 \pm 0,002$ & $2,13 \pm 0,002$ & $2,12 \pm 0,002$ & GOST 5867-90 \\
\hline $\begin{array}{l}\text { Carbohydrates g, } \\
\text { not more than }\end{array}$ & $6,72 \pm 0,33$ & $6,74 \pm 0,33$ & $6,73 \pm 0,33$ & $6,72 \pm 0,33$ & $6,71 \pm 0,33$ & $\begin{array}{l}\text { I.M. Skurikhin. } \\
\text { issue } 1 \text { - } 1987\end{array}$ \\
\hline Moisture & $87,43 \pm 0,09$ & $87,45 \pm 0,09$ & $87,44 \pm 0,09$ & $87,43 \pm 0,09$ & $87,42 \pm 0,09$ & GOST 3626-73 \\
\hline SOMO, $\%$ & $12,57 \pm 0,09$ & $12,59 \pm 0,09$ & $12,58 \pm 0,09$ & $12,57 \pm 0,09$ & $12,56 \pm 0,09$ & $\begin{array}{l}\text { GOST R } \\
54761-2011\end{array}$ \\
\hline Ash & $0,89 \pm 0,04$ & $0,91 \pm 0,04$ & $0,90 \pm 0,04$ & $0,89 \pm 0,04$ & $0,88 \pm 0,04$ & GOST 15113.8-77 \\
\hline $\begin{array}{l}\text { Energy value, } \\
\mathrm{kcal} / \mathrm{kJ} / 100 \mathrm{~g}\end{array}$ & $57 / 238$ & $59 / 240$ & $58 / 239$ & $57 / 238$ & $56 / 237$ & $\begin{array}{l}\text { I.M. Skurikhin. } \\
\text { issue } 1 \text { - } 1987\end{array}$ \\
\hline
\end{tabular}

Table 9: Comparative quality indicators of goat milk yoghurts

\begin{tabular}{|c|c|c|c|c|}
\hline \multirow{2}{*}{$\begin{array}{l}\text { Name of indicators, } \\
\text { units of measurement }\end{array}$} & \multirow[b]{2}{*}{$\begin{array}{l}\text { Permissible Norms for } \\
\text { NDaccording to } \\
\text { regulatory documents }\end{array}$} & \multicolumn{2}{|c|}{ Actual Received } & \multirow[b]{2}{*}{$\begin{array}{l}\text { Regulatory documents } \\
\text { designation for test } \\
\text { methods }\end{array}$} \\
\hline & & $\begin{array}{l}\text { Goat's milk } \\
\text { yogurt }\end{array}$ & $\begin{array}{l}\text { Goat's milk } \\
\text { yogurt with } \\
\text { dates }\end{array}$ & \\
\hline \multicolumn{5}{|l|}{$\begin{array}{l}\text { Nutritional value, g / } \\
\text { 100g: }\end{array}$} \\
\hline $\begin{array}{l}\text { Proteins, at least (for } \\
\text { dairy products-in the } \\
\text { milk base) }\end{array}$ & $\begin{array}{l}2-3,2 \text { for preventive } \\
\text { nutrition - not more than } \\
4 .\end{array}$ & $4,00 \pm 0,002$ & $2,83 \pm 0,002$ & ГОСТ 23327-98 \\
\hline Fats & $2-4$ & $1,17 \pm 0,001$ & $2,13 \pm 0,002$ & GOST 5867-90 \\
\hline $\begin{array}{l}\text { Carbohydrates g, not } \\
\text { more than }\end{array}$ & 12 & $3,93 \pm 0,2$ & $6,72 \pm 0,33$ & $\begin{array}{l}\text { I. M. Skurikhin. vol.1, } \\
1987 .\end{array}$ \\
\hline Moisture & - & $90,17 \pm 0,09$ & $87,43 \pm 0,09$ & GOST 3626-73 \\
\hline SOMO, \% & $0,5-99,0$ & $9,83 \pm 0,09$ & 12,57 & GOST R 54761-2011 \\
\hline Ash & $0,5-0,8$ & $0,73 \pm 0,03$ & $0,89 \pm 0,04$ & GOST 15113.8-77 \\
\hline $\begin{array}{l}\text { Energy value, } \mathrm{kcal} / \mathrm{kJ} / \\
100 \mathrm{~g}\end{array}$ & - & $42 / 176$ & $57 / 238$ & $\begin{array}{l}\text { I. M. Skurikhin. vol.1, } \\
1987 .\end{array}$ \\
\hline
\end{tabular}


Table 10: Physical and chemical parameters of yogurt with dates from goat's milk

\begin{tabular}{|c|c|c|c|}
\hline \multirow{2}{*}{$\begin{array}{l}\text { Name of indicators, units of } \\
\text { measurement }\end{array}$} & \multirow{2}{*}{$\begin{array}{l}\text { Acceptable standards for } \\
\text { ND }\end{array}$} & The actual obtained & \multirow{2}{*}{$\begin{array}{l}\text { ND designation for test } \\
\text { methods }\end{array}$} \\
\hline & & $\begin{array}{l}\text { Goat's milk yogurt } \\
\text { with dates }\end{array}$ & \\
\hline \multicolumn{4}{|l|}{ Nutritional value, g / 100g: } \\
\hline $\begin{array}{l}\text { Proteins, at least (for dairy } \\
\text { products-in the milk base) }\end{array}$ & $\begin{array}{l}2-3,2 \text { for preventive } \\
\text { nutrition-no more than } \\
4 .\end{array}$ & $2,83 \pm 0,002$ & GOST 23327-98 \\
\hline Fats & $2-4$ & $2,13 \pm 0,002$ & GOST 5867-90 \\
\hline Carbohydrates g, not more than & 12 & $6,72 \pm 0,33$ & $\begin{array}{l}\text { I. M. Skurikhin. vol. } 1 \\
1987\end{array}$ \\
\hline Moisture & - & $87,43 \pm 0,09$ & GOST 3626-73 \\
\hline SOMO, $\%$ & $0,5-99,0$ & 12,57 & GOST R 54761-2011 \\
\hline Ash & $0,5-0,8$ & $0,89 \pm 0,04$ & GOST 15113.8-77 \\
\hline Energy value, $\mathrm{kcal} / \mathrm{kJ} / 100 \mathrm{~g}$ & - & $57 / 238$ & $\begin{array}{l}\text { I. M. Skurikhin. vol. } 1 \\
1987\end{array}$ \\
\hline
\end{tabular}

